\title{
BEDAH LOGO AUTOCILLIN MENGGUNAKAN TEORI SEMIOTIKA
}

\author{
Sari Wulandari \\ Jurusan Desain Komunikasi Visual, Fakultas Komunikasi dan Multimedia, \\ Bina Nusantara University, Jln. K.H. Syahdan No 9, Palmerah, Jakarta 11480 \\ swulandari@binus.edu
}

\begin{abstract}
When a brand will communicate with people through visual media, then a visual communication designer will act as the sender in meaningful visual. A vehicle product assurance, Autocillin, will launch its brand; therefore it needs to presence visual identity of Autocillin, which is able to change people's perception about assurance and also to represent brand image according to its ideals and hopes with its philosophy. Research method uses theory approach of semiotic theory from Peirce with its developing on icon, index and symbol. It also uses semiotic theory from Charles Morris of its semiotic processes: syntax, semantic, and pragmatic; and Roland Barthes approach of semiotic analysis towards design. It will be concluded that through visual identity, Autocillin could answer needs in communicating unprecedented experience of its consumers and change people's perception of vehicle assurance. Through sign approach, Autocillin is ready to interact and compete with other brands.
\end{abstract}

Keywords: Autocillin, assurance, logo, semiotic

\begin{abstract}
ABSTRAK
Ketika sebuah merek akan berkomunikasi dengan masyarakat melalui media visual, maka seorang desainer komunikasi visual yang akan bertindak sebagai pengirim pesan dalam bentuk visual yang memiliki makna. Sebuah produk asuransi kendaraan bermotor Autocillin akan meluncurkan mereknya, untuk itu dibutuhkan kehadiran identitas visual Autocillin yang dapat mengubah persepsi masyarakat mengenai asuransi sekaligus merepresentasikan citra merek yang sesuai dengan cita-cita dan harapan para pembangun merek Autocillin, dengan mengedepankan filosofinya. Pembedahan menggunakan pendekatan teori Semiotika dari Peirce dengan pengembangannya pada ikon, indeks dan simbol, serta teori Semiotika hasil pengembangan dari Charles Morris pada proses semiosis yaitu sintaks, semantik dan pragmatik, serta pendekatan Roland Barthes mengenai analisis semiosis pada desain. Selanjutnya maka dapat disimpulkan bahwa melalui identitas visual yang dimilikinya, Autocillin dapat menjawab kebutuhan dalam mengkomunikasikan unprecedented experience bagi konsumennya serta dapat mengubah persepsi masyarakat mengenai asuransi kendaraan bermotor. Melalui pendekatan tanda, sebuah merek Autocillin siap untuk berinteraksi dan bersaing.
\end{abstract}

Kata kunci: Autocillin, asuransi, logo, semiotika 


\section{PENDAHULUAN}

Pada bulan September 2003 Adira Insurance, merupakan anak perusahaan Adira Group yang saat itu akan membuat produk asuransi kendaraan bermotor yang dikembangkan sebagai merek dengan nama Autocillin di mana unprecedented experience merupakan filosofi pelayanannya, dengan produk dan fitur yang unique, simple \& reliable. Pada saat itu banyak masyarakat Indonesia belum sepenuhnya menganggap asuransi itu penting, bahkan cenderung memandangnya sebagai pengeluaran ekstra yang tidak perlu. Padahal apapun aktivitas yang dilakukan oleh manusia pasti mengandung risiko. Demikian pula dengan berkendara, meskipun dilakukan dengan sangat hati-hati namun bila kurang beruntung risiko dapat pula terjadi. Oleh karenanya perlu diambil langkah antisipasi untuk meminimalisir risiko, yaitu dengan mengasuransikan kendaraan bermotor. Tentunya hal ini menjadi tantangan bagi Adira Insurance untuk dapat mengubah pandangan masyarakat mengenai asuransi pada umumnya dan asuransi kendaraan bermotor pada khususnya.Selain itu Adira memiliki pesaing besar dimana pada saat produk diluncurkan, masyarakat sudah mengenal produk asuransi kendaraan bermotor milik Astra Group yaitu Garda Oto, yang telah menduduki posisi top of mind di benak masyarakat untuk produk asuransi kendaraan bermotor. Secara demografis, masyarakat yang menjadi target pasar Autocillin adalah usia dewasa, mayoritas gender pria, status ekonomi dan sosial menengah ke atas dengan pekerjaan sebagai profesional dan wirausahawan.

Sebuah karya Desain Komunikasi Visual merupakan medium yang memiliki kemampuan sangat kuat dalam hal penyampaian sebuah pesan, mengubah persepsi serta membangun pencitraan. Oleh karena itu maka dibutuhkan kehadiran identitas visual Autocillin yang dapat mengubah persepsi masyarakat mengenai asuransi sekaligus merepresentasikan citra merek yang sesuai dengan cita-cita dan harapan para pembangun merek Autocillin, dengan mengedepankan filosofi unprecedented experience. Filosofi inidijadikan platform untuk semua pengembangan identitas produk--nama, simbol, positioning statement, graphic style dan lain sebagainya, dan kemudian diciptakanlah logo Autocillin yang sering dijumpai di masyarakat.

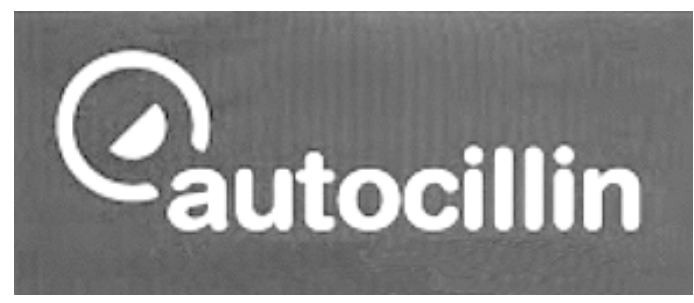

Gambar 1 Logo Autocillin

Ketika sebuah merek akan berkomunikasi dengan masyarakat melalui media visual, maka seorang desainer komunikasi visual yang akan bertindak sebagai pengirim pesan dimana pesan yang akan disampaikan dikemas dalam bentuk visual yang memiliki makna. Di sinilah letak kekuatan bahasa rupa. Sangatlah penting bagi seorang desainer komunikasi visual untuk memperhatikan pemaknaan dari bahasa tanda. Hal ini dikarenakan selain penyajian visual harus unik dan menarik, juga harus dapat dipahami oleh masyarakat yang dituju sehingga hasilnya akan komunikatif. Sebaliknya, apabila penyampaian pesan dilakukan tanpa memperhatikan situasi dan kondisi masyarakat yang dituju, maka komunikasi akan gagal dan usaha yang telah diupayakan menjadi tidak berarti. Oleh karenanya dalam menciptakan sebuah karya komunikasi visual seorang desainer harus memperhatikan pemaknaan yang tertuang pada bahasa rupa (gambar, tulisan, warna). 
Metode penyampaian pesan di area Desain Komunikasi Visual sangat erat hubungannya dengan bahasa rupa baik itu bahasa visual (medium gambar) maupun bahasa verbal (medium tulisan) dengan cara mengolah elemen desain grafis berupa foto, ilustrasi, tipografi, warna, layout dan lainlain. Bahasa sendiri merupakan sistem perlambangan yang digunakan untuk berkomunikasi dan berinteraksi, di mana lambang-lambang tersebut dapat dipahami oleh kedua belah pihak, baik pengirim pesan maupun penerima pesan. Dalam bahasa lisan setiap kata yang diucapkan, dengan artikulasi tertentu, memiliki arti dan pemahamannya masing-masing. Kata-kata yang diucapkan bisa jadi sama, namun dengan pendekatan yang berbeda akan menghasilkan pemahaman yang berbeda dan menimbulkan efek psikologis yang berbeda pula. Demikian pula halnya dengan lambang. Setiap lambang memiliki arti dan yang lebih penting lagi perlu disadari bahwa menampilkan lambang dapat dilakukan dengan berbagai cara dan masing-masing cara akan menimbulkan makna serta pemahaman tersendiri.

Melalui bedah logo dan kaitannya dengan bahasa tanda, maka akan dapat diketahui bagaimana logo Autocillin ini dapat mengubah persepsi masyarakat baik mengenai asuransi secara umum, maupun khususnya asuransi kendaraan bermotor, serta bagaimana logo Autocillin ini dapat mengimbangi popularitas merek Garda Oto yang sudah lebih dahulu dikenal oleh masyarakat pada saat itu.

Logo merupakan bagian dari identitas merek. Menurut Alina Wheeler (2003), identitas yang baik dapat merepresentasikan dan meningkatkan reputasi merek. Hal ini dapat dicapai melalui terbentuknya persepsi yang diinginkan. Identitas ini mengarahkan setiap materi pengekspresian merek (brand experience) yang dapat terukur dan menjadi bagian dari budaya perusahaan. Dengan sendirinya hal ini dapat menjadi sebuah reminder di benak masyarakat yang secara terusmenerus dapat menyampaikan semangat yang dimiliki oleh merek, sehingga terbentuk perilaku yang diharapkan oleh perusahaan yang akhirnya menghasilkan performa yang baik; seperti digambarkan pada Gambar 2.

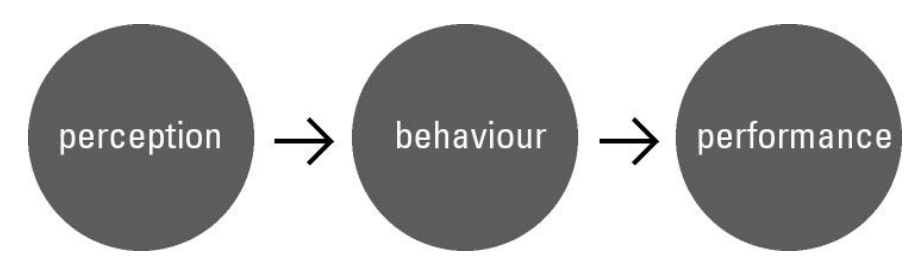

Gambar 2 Pengekspresian Merek

Dewasa ini visualisasi identitas merek khususnya logo berkembang sangat pesat, dari yang literal ke arah simbolik, dari yang berbasis arahan-kata ke arahan-gambar. Oleh karenanya logo dapat divisualisasikan dengan berbagai macam cara. Namun secara garis besar menurut Wheeler (2003) logo dapat dikelompokkan ke dalam tiga kategori: (1) wordmarks, yaitu terjemahan bebas dari nama merek, dapat berupa nama perusahaan atau singkatan seperti pada logo IBM, Braun, Mobil; (2) letterform marks, menggunakan sebuah huruf yang direpresentasikan secara unik dengan makna dan karakter yang sangat kuat, seperti logo M pada merek Motorola; (3) brandmarks, menggunakan visual berupa figur yang merupakan simbolisasi dari misi, visi atau nilai utama dari perusahaan. Brandmarks terbagi menjadi Pictorial Brandmarks (yaitu logo yang menampilkan visual berupa figur yang mudah dikenali) dan Abstract Brandmarks (yaitu logo yang menggunakan figur abstrak).

Teori yang mempelajari bahasa tanda dikenal dengan teori Semiotika. Dalam perkembangannya, Semiotika adalah ilmu yang mempelajari tentang tanda (sign), tentang berfungsinya sebuah tanda dan terciptanya sebuah makna. Tanda-tanda tersebut menyampaikan suatu informasi sehingga bersifat komunikatif. Cabang ilmu ini semula berkembang dalam bidang bahasa, kemudian berkembang pula dalam bidang seni rupa dan Desain Komunikasi Visual, menjadi sebuah 
metodologi yang mengeksplorasi struktur untuk membantu menyibak makna yang terkandung dalam sebuah karya desain, bahkan dalam sebuah aktivitas budaya.

Sekitar tahun 1960an, desainer mulai menyadari peran ilmu semiotika sebagai sebuah cara untuk memahami sebuah karya desain dan sebaliknya untuk membantu agar sebuah karya desain dapat berkomunikasi secara tepat kepada konsumennya. Tidaklah mengherankan bagaimana cabang ilmu ini dapat berkembang pesat mengingat salah satu kebutuhan manusia adalah berkomunikasi. Manusia berkomunikasi melalui tanda yang direpresentasikan dalam bentuk gerakan, isyarat, suara, tulisan, gambar, dan lain-lain di mana bentuk-bentuk ini sangat dekat dengan karya-karya yang dihasilkan oleh seorang desainer komunikasi visual. Oleh karena itu sangat tepat apabila Teori Semiotika digunakan sebagai alat bantu bedah sebuah karya Desain Komunikasi Visual karena dalam proses penciptaannya dimana seorang desainer akan mempertimbangkan pemilihan elemen-elemen desain serta prinsip desain yang sesuai dalam mengatur elemen-elemen desain sehingga dapat menimbulkan makna yang tepat bagi target audiensnya.

Dalam keilmuan DKV dikenal dua orang tokoh semiotika, yaitu Ferdinand de Saussure (18571913) dan Charles Sander Peirce (1839-1914). Saussure yang memiliki latar belakang lingusitik menyebut ilmu ini Semiology, sedangkan Pierce yang berlatar belakang filsafat menyebutnya Semiotics.

Semiology, menurut Saussure, didasarkan pada anggapan bahwa selama perbuatan dan tingkah laku manusia membawa makna atau selama berfungsi sebagai tanda, berarti di belakangnya terdapat sistem pembedaan dan konvensi yang memungkinkan terbentuknya makna itu. Di mana ada tanda, maka di sana ada sistem. Artinya: sebuah tanda mempunyai 2 aspek yang ditangkap oleh manusia. Yang pertama adalah yang disebut dengan Signifier, yaitu penanda atau sesuatu yang terlihat dan mempunyai wujud seperti bunyi, huruf, kata, gambar, warna, obyek, dan lain-lain. Aspek kedua adalah yang disebut dengan Signified, yaitu petanda atau konsep atau makna.Kedua aspek ini sifatnya Arbiter (terpisah, tidak ada hubungan).

\section{Signifier \\ (physical sign)}

$\overline{\begin{array}{c}\text { Signified } \\ \text { (mental concept) }\end{array}}$

Gambar 3 Dua Aspek Semiologi

Sedangkan semiotika menurut Peirce, penalaran manusia senantiasa dilakukan lewat tanda. Tanda baru dapat berfungsi apabila diintepretasikan di dalam benak penerima tanda, melalui pemahaman makna yang muncul dalam diri penerima tanda. Dengan kata lain, sebuah visual dapat berfungsi sebagai tanda apabila memiliki 3 komponen yang dikenal dengan Triadic Semiotic, yaitu memiliki Representamen (sesuatu yang direpresentasikan), ada Obyek (kerangka acuan atau makna) dan ada Interpretan (memungkinkan adanya interpretasi). Untuk lebih jelasnya dapat dilihat pada diagram Peirce (Gambar 4). 


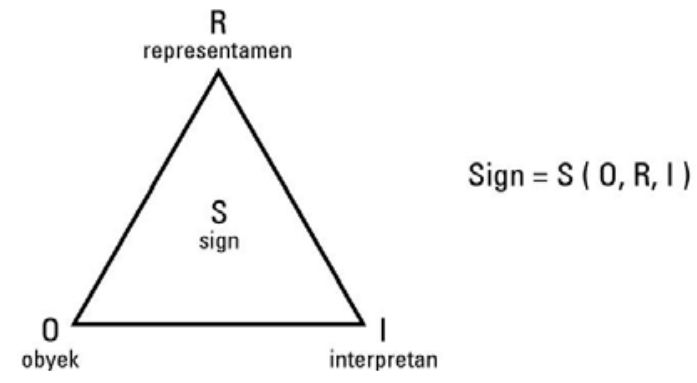

Gambar 4 Diagram Pierce

Dengan demikian, sebuah tanda dapat diteliti, dipelajari dan berfungsi sebagai pintu masuk untuk mengetahui terciptanya sebuah ekspresi, representasi dan selanjutnya dapat menimbulkan pengetahuan baru, seperti yang tergambar pada diagram di Gambar 5.

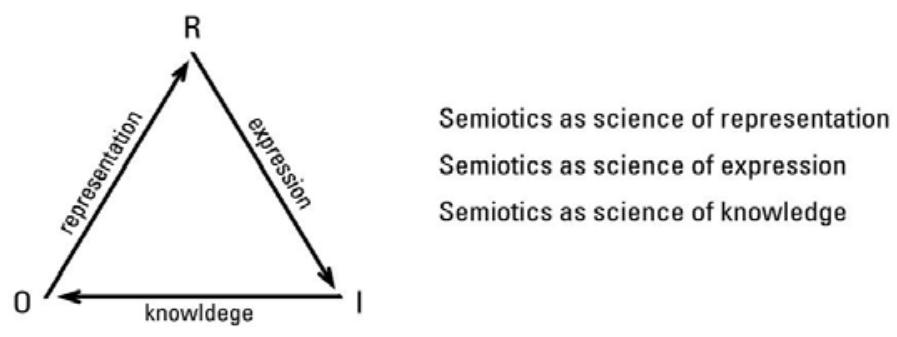

Gambar 5 Revisi Diagram Pierce

Ilmu desain berkembang lintas disiplin ilmu secara luas dan berproses secara heterogen. Oleh karenanya tidak tertutup kemungkinan di mana tanda dapat memiliki berbagai macam interpretasi. Tanda (representamen) sebagai representasi dari sebuah Obyek dapat diklasifikasikan menjadi 3 jenis tanda.Yang pertama adalahikon, yaitu tanda di mana antara tanda dengan acuannya terdapat hubungan kemiripan (metafora). Pada Ikon, Representamen merupakan representasi dari Obyek dan Interpretan mengacu kepada keduanya. Contohnya, potret wajah merupakan representasi dari sebuah wajah dan interpretan membuat hubungan antara keduanya. Yang kedua adalah indeks yaitu apabila ada hubungan kedekatan eksistensi antara tanda dengan acuannya.Pada indeks, interpretan cukup mengacu pada representamen saja karena representamen merupakan representasi dari obyek. Contohnya, dengan melihat adanya asap maka interpretan dapat mengetahui adanya api.Yang terakhir adalahsimbol, yaitu apabila tanda diakui keberadaannya berdasarkan hukum konvensi. Pada simbol, interpretan memiliki hubungan dengan obyek dan hubungan dengan representamen namun obyek dan representamen tidak berhubungan secara langsung. Contohnya, interpretan menganggap benda untuk menyimpan uang adalah dompet dan interpretan menulis benda tersebut sebagai d-o-m-p-e-t, namun antara benda dan d-o-m-p-e-t tidak ada hubungan secara langsung.Penjelasan mengenai hubungan representamen-obyek-interpretan pada pemaknaan ikon, indeks dan simbol dapat dilihat melalui diagram Peirce pada Gambar 6.
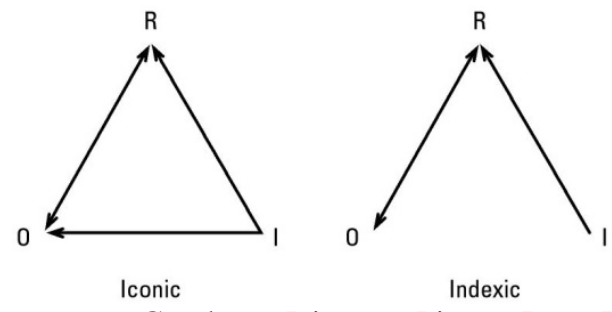

Gambar 6 Diagram Pierce: Icon, Indeks, Simbol

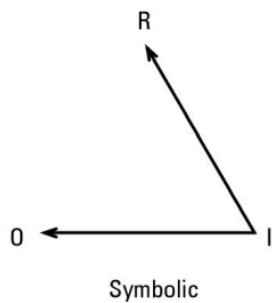


Tokoh semiotika lainnya, Charles Morris (1901-1979) mengikuti Peirce dalam menggunakan istilah "semiotic" dengan mengembangkan pemakaian tanda dan pemaknaannya serta menghubungkan tanda tersebut dengan perilaku. Ia menambahkan bahwa terjadi tingkatan semiotika dimana tanda berproses secara bertahap yaitu (1) sintaks dimana terdapat hubungan antara satu tanda dengan tanda lain, di mana tanda menjadi Representamen. Sintaks tidak hanya dibatasi mempelajari hubungan antara tanda di dalam sistem tanda yang sama, melainkan juga mempelajari tanda dalam sistem lain yang menunjukkan kerjasama. Misalnya dalam film, antara gambar dan kata-kata, pada dasarnya berasal dari sistem tanda yang berbeda, namun keduanya bekerjasama. Dalam linguistik, sintaks merupakan ilmu yang mempelajari prinsip-prinsip dan aturan dalam membangun kalimat. Dalam disiplin keilmuan DKV, sintaks mempelajari prinsip-prinsip desain dan hubungan antar elemen grafis, dalam perancangan sebuah desain.; (2) semantik, yaitu hubungan antara tanda (representamen) dengan obyek, sehingga menimbulkan makna. Semantik merupakan ilmu yang mempelajari pemaknaan tanda yang digunakan oleh masyarakat tertentu dalam situasi dan konteks tertentu. Mengingat pemaknaan ini terkait dengan situasi dan konteks tertentu, maka dalam Semantik dikenal adanya semantik denotatif, yaitu makna yang tersirat dan semantik konotatif, yaitu makna yang tersurat; (3) pragmatik, yaitu pemaknaan (hasil semantik representamen kepada obyek) yang dihubungkan dengan penggunanya (interpretan) sehingga konteks penggunaan tanda dapat teridentifikasi. Makna sebuah representamen dapat berubah, tergantung pada interpretan.
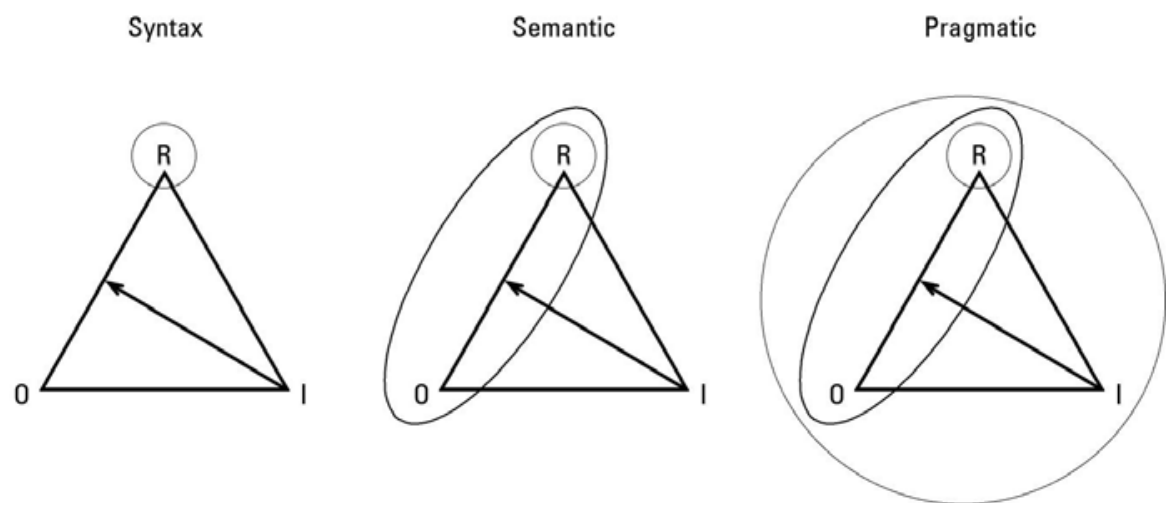

Gambar 7

Agar tanda dapat berfungsi maka representamen diterjemahkan ke dalamGround, yaitu sistem tanda yang ada dalam suatu masyarakat, biasanya berbentuk Kode. Salah satu contoh Kode adalah bahasa, di mana pada prakteknya sebuah pesan dikirim oleh pengirim pesan melalui seperangkat kode yaitu susunan huruf yang membentuk kata (yang dipahami melalui sebuah konvensi) oleh penerima pesan. Seseorang dapat melakukan komunikasi karena adanya ground yang berbentuk Kode. Ketika hendak mengirim pesan ia melakukan encoding (menterjemahkan makna ke dalam ground) dan ketika menerima pesan ia melakukan decoding (mengintepretasikan ground untuk menangkap makna).

Proses komunikasi ini dapat dijelaskan melalui Model Komunikasi dari Wilbur Schramm (1954) yang mempopulerkan Schramm's Interactive Model. Dijelaskan di dalam bukunya The Process and Effects of Communication, bahwa proses decoding dan encoding adalah aktivitas yang terjadi secara terus menerus yang dilakukan oleh pengirim dan penerima pesan sehingga terjadi komunikasi dua arah. Ia menegaskan bahwa hal ini dimungkinkan dengan adanya peran interpreter (secara abstrak) dalam memecahkan masalah pemaknaan. Untuk lebih jelasnya dapat dilihat pada diagram Komunikasi Model Wilbur Schramm pada gambar 8. 


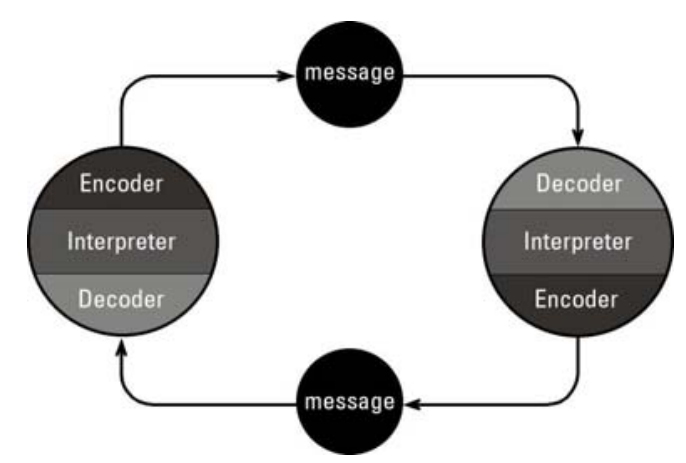

Gambar 8 Komunikasi Model Wilbur Schramm

Roland Barthes mengembangkan metode semiotika untuk desainer melalui analisinya terhadap kompleksitas tanda dengan melihat pengalaman konsumen terhadap desain. Bukunya berjudul Mythologies (1957) adalah yang pertama mengembangkan sebuah analisis semiologis dari desain, di mana ia mengenalkan 3 tingkatan dalam pemaknaan sebuah tanda. Tingkat pertama adalah pemaknaan secara denotatif, yaitu makna tertangkap secara langsung. Misalnya figur pada gambar mobil balap berarti 'ini adalah mobil sport'. Tingkat kedua adalah pemaknaan secara konotatif, yaitu makna yang tersirat secara tidak langsung, dimana figur gambar mobil balap dimaknakan sebagai 'kehidupan moderen yang serba cepat'. Tingkatan yang ketiga adalah mitologi. Pengertian mitologi disini adalah mitos-mitos yang hidup di era moderen baik dalam lingkup kebendaan, peran maupun karakter. Mitologi terbentuk melalui pemikiran mitos yang dipadukan dengan pemikiran rasional. Gambar mobil balap disini secara mitologi dapat menyimbolkan 'kekuatan, kekuasaan, kebebasan' namun tergantung pada profil masyakat yang melihat (gender, usia, kelas). Dengan mempelajari mitos dapat diketahui bagaimana sebuah kelompok masyarakat menjawab permasalahan yang ada di dalam kehidupan mereka. Selanjutnya dapat diketahui bagaimana latar belakang sekelompok manusia dalam mengembangkan tatanan kehidupan, prinsip hidup serta nilai-nilai yang dapat menyatukan mereka ke dalam sebuah kelompok sosial.

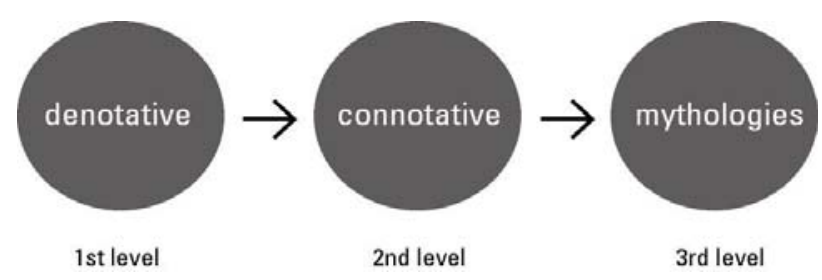

Gambar 9 Metode Semiotika oleh Barthes

Menurut Richard Grefé dalam AIGA Journal for the Network Economy (2000), ketika desain grafismulai berhubungan dengan komunikasi, desain dalam lingkup komunikasi menjadi sebuah disiplin yang menyangkut form dan content. Dewasa ini dengan berjalannya waktu,experience designdi mana sudah menjadi sesuatu hal yang dibentuk oleh realita komunikasi saat ini.mempertimbangkan unsur form, content dan context dari komunikasi. Ketiga unsur ini diketahui memilikipengaruh pada brand experiencemasyarakat.

Berdasarkan proses desain yang dijelaskan oleh David Smith (2010), form, content dan context berkaitan erat dengan proses semiosis dari Morris yaitu sintaks merupakan dengan form (tampilan visual/representamen), semantik merupakan content (pesan yang akan disampaikan/obyek) dan pragmatik merupakan context (mempertimbangkan kebutuhan, profil penerima pesan/interpretan). Untuk lebih jelasnya dapat dilihat pada diagram Gambar 11. 


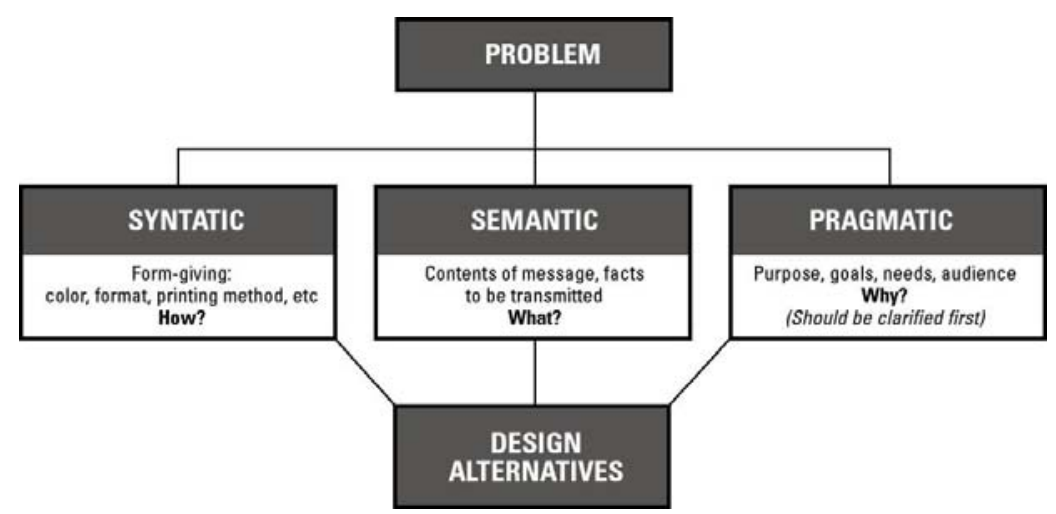

Gambar 11 Proses desain

\section{METODE PENELITIAN}

Dalam kasus ini adalah membedah logo Autocillin melalui pendekatan teori Semiotika dari Peirce dengan pengembangannya pada ikon, indeks dan simbol, serta teori Semiotika hasil pengembangan dari Charles Morris pada proses semiosis yaitu sintaks, semantik dan pragmatik, karena teori ini dipandang lengkap dan dekat dengan karakteristik Desain Komunikasi Visual; serta pendekatan Roland Barthes analisis semiosis pada desain.

\section{HASIL DAN PEMBAHASAN}

Logo Autocillin terdiri dari brandmarks dan wordmarks. Keduanya adalah komponen yang saling melengkapi dan tidak dapat dipisahkan. Yang disebut brandmarks adalah visual berupa gambar lingkaran, sedangkan wordmarks adalah nama merek 'autocillin'.

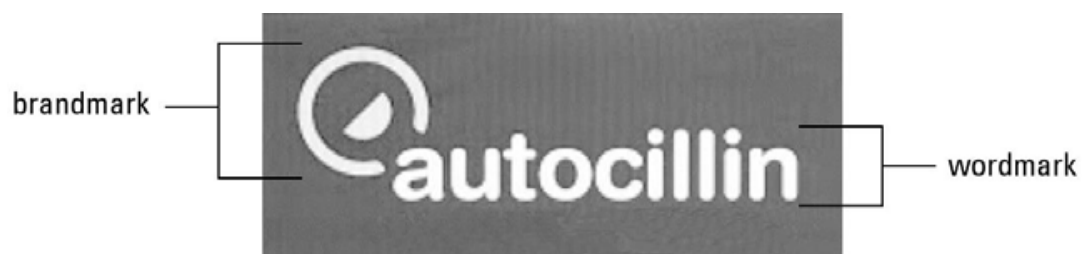

Gambar 12 Tampilan logo Autocillin dengan brandmark dan wordmark

Melalui tampilan logo pada Gambar 12, penulis akan mengawali kajian dengan membedah logo melalui pendekatan struktural yang berlandaskan teori Pierce mengenai ikon, indeks dan simbol. Logo Autocillin sendiri terdiri dari kumpulan tanda-tanda yang dapat dipisahkan menjadi dua bagian yaitu pembedahan melalui visual (logo) dan pembedahan melalui verbal (naming).

Secara denotatif dan kasat mata, dapat dilihat visual yang terdapat dalam tampilan logo Autocillin disini masuk dalam kategori ikon karena komposisi bentuk lingkaran besar dan setengah lingkaran kecil membentuk huruf U berwarna kuning menggambarkan wajah manusia yang sedang tersenyum (metafora). Hal ini dapat disimpulkan berdasarkan penelitian seorang psikolog Paul Ekman pada tahun 1963 bahwa ekspresi wajah manusia merupakan bahasa yang sangat universal yang 
memiliki persamaan lintas kultur. Ia menjabarkan ekspresi wajah manusia menjadi beberapa komponen-posisi alis, bentuk mata, bentuk mulut, dan lain sebagainya-di mana berbagai macam kombinasi dari komponen ini dianggap sebagai form dan ekspresi yang dihasilkan sebagai content.
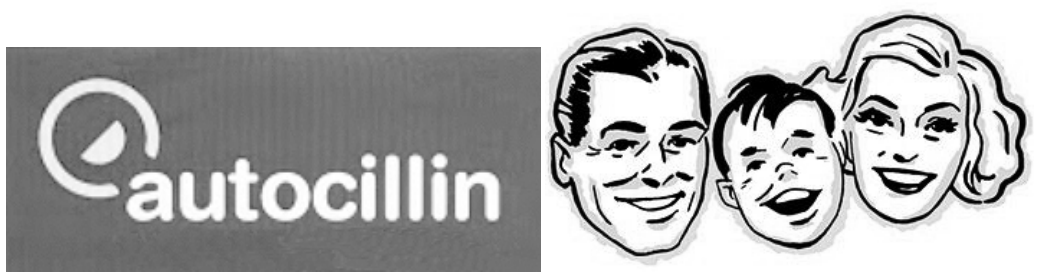

Gambar 13 Logo dengan metafora wajah manusia

Di samping pemaknaan kategori ikon, pada brandmark logo Autocillin juga terdapat pemaknaan dalam kategori lainnya. Tanda berbentuk lingkaran dalam konteks kendaraan merujuk kepada bentuk kemudi dari kendaraan roda empat. Petanda ini masuk ke dalam kategori indeks di mana sebuah kemudi merupakan bagian dari kendaraan beroda empat. Pemilihan kemudi sebagai ground dalam menyampaikan pesan 'kendaraan roda empat' ini dinilai cukup unik dimana pada umumnya ditampilkan roda atau figur mobil sebagai ground untuk kendaraan roda empat.

Selanjutnya, visual kemudi ini diposisikan secara asimetris seolah-olah pengendara mengarahkan kendaraan ke kiri. Secara konotatif hal ini merupakan ground untuk menyampaikan pesan bahwa bila kendaraan berada dalam kondisi darurat maka kendaraan harus ditepikan di bagian kiri jalan agar situasi menjadi aman.
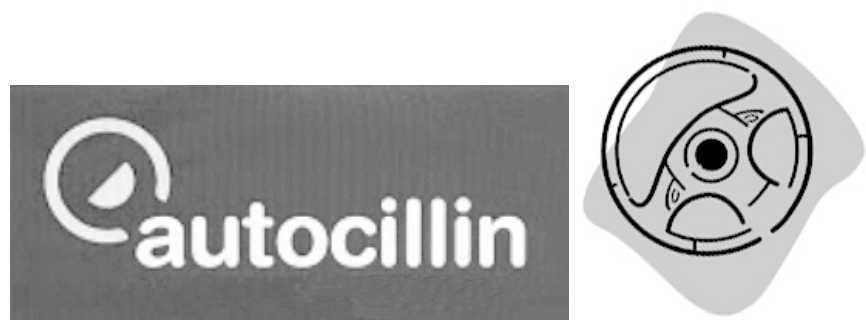

Gambar 14 Logo dengan visual kemudi asimetris

Selain ikon dan indeks, pada logo Autocillin juga terdapat pemaknaan tanda berupa simbol. Simbol dapat ditemui melalui warna yang diterapkan pada brandmark yaitu penggunaan warna kuning di atas bidang warna biru tua. Kombinasi warna ini memiliki kontras yang tinggi, sehingga sangat mudah dilihat. Hal ini memiliki pendekatan yang sama sebagaimana yang dilakukan oleh rambu lalu lintas di mana menggunakan kombinasi warna kuning dan hitam sehingga representamen dapat mudah dilihat dan dikenali.

Ditinjau melalui proses semiosis hasil pendekatan teori semiotika dari Charles Morris, diketahui bahwa terjadi proses sintaks pada brandmark ketika tanda berupa lingkaran besar bekerjasama dengan tanda setengah lingkaran kecil untuk menghasilkan sebuah representamen ikonik yaitu figur happy face. Dalam kesempatan yang sama brandmark bekerjasama dengan wordmark, sehingga pada konteks 'auto' (kendaraan) maka tanda pada brandmark di-encode menjadi representamen indeks dari figur kemudi. Ketika representamen dikomunikasikan dalam kerangka acuan 'asuransi' sebagai obyek, maka selanjutnya terjadi proses semantik di mana representamen yang tampil pada logo memiliki makna konotatif 'kenyamanan berkendara'. 
Di samping itu proses sintaks juga terjadi pada wordmark di mana terdapat hubungan yang menarik pada nama merek itu sendiri. Apabila nama merek Autocillin dijabarkan lebih rinci, maka dapat diketahui bahwa nama merek terdiri dari dua kata yaitu 'auto' dan 'cillin'. Auto dapat berarti 'kendaraan' atau 'dengan sendirinya' sedangkan cillin adalah nama obat jenis antibiotika. Ketika kedua kata ini bekerjasama maka terbentuk representamen 'mengobati kendaraan' atau 'terobati dengan sendirinya'. Apabila dihubungkan dengan konteks 'asuransi' di mana manfaat akan dituai ketika risiko terjadi, maka selanjutnya terjadi proses semantik bermakna konotatif yaitu 'dengan Autocillin ketika terjadi risiko maka luka lahiriah (pada mobil) dan luka batiniah (pada pemilik) dengan sendirinya akan terobati'. Secara pragmatis pemaknaan ini hanya dapat ditangkap oleh masyarakat yang bersinggungan secara langsung dengan hal-hal yang menyangkut asuransi kendaraan bermotor.

Dari pendekatan Roland Barthes mengenai analisis semiologis pada desain, pada logo Autocillin diketahui terdapat 3 tingkatan dalam pemaknaan sebuah tanda, yaitu denotatif dengan pemaknaan 'kenyamanan berkendara',konotatif dengan pemaknaan 'kenyamanan berkendara karena kendaraan selalu dalam kondisi sehat'. Kedua tingkat pemaknaan ini telah dijelaskan sebelumnya melalui proses semiosis Morris. Tidak berhenti hingga disini, pada logo Autocillin terdapat tingkat pemaknaan selanjutnya yaitu mitologi. Tanda pada brandmark berbentuk lingkaran yang terbuka pada sisi bagian bawah membentuk representamen 'tapal kuda'. Figur tapal kuda bagi dikenal oleh sebagian kelompok masyarakat kuno sebagai simbol keamanan. Pengertiannya adalah bahwa manusia mengendarai kuda sebagai kendaraannya maka sudah selayaknya tapal kuda dikenakan pada kuda dengan sebaik-baiknya. Hal ini penting untuk melindungi kaki kuda tunggangan sehingga manusia dapat menunggang dengan aman dan nyaman. Apabila dikaitkan dengan mitologi saat ini, maka makna yang terbentuk adalah 'agar pengendara dapat berkendara dengan aman maka kendaraan perlu dilengkapi dengan asuransi yang tepat'.

\section{SIMPULAN}

Upaya yang dilakukan oleh Adira Insurance untuk dapat mengubah pandangan masyarakat mengenai asuransi pada umumnya dan asuransi kendaraan bermotor pada khususnya dapat terwujud melalui kehadiran identitas visual Autocillin yang dapat mengkomunikasikan citra merek dengan mengedepankan filosofi unprecedented experience sebagaifilosofi pelayanannya. Dalam lingkup pengelompokan brandmarks, logo Autocillin masuk ke dalam kategori Pictorial brandmarks karena visual yang ditampilkan menghasilkan ikon berupa wajah orang yang sedang tersenyum (happy face), indeks dari mobil berupa kemudi. serta pemaknaan simbol dengan pengaplikasian warna kuning dan biru tua berkontras tinggi pada logo sebagaimana halnya pada rambu lalu lintas (kembali lagi kaitannya kepada konteks kendaraan). Brandmark juga memiliki makna konotatif melalui tanda-tanda pada logo menyiratkan makna 'berkendara dengan aman dan nyaman'. Bahkan pada tingkatan berikutnya terdapat mitologi tapal kuda sebagai simbol keamanan yang bila dikaitkan dengan kondisi saat ini ternyata masih relevan.

Dari penjabaran di atas maka dapat disimpulkan bahwa logo Autocillin dapat menjawab kebutuhan diciptakannya identitas visual yang dapat mengkomunikasikan unprecedented experience bagi konsumennya serta dapat mengubah persepsi masyarakat baik mengenai asuransi secara umum, maupun khususnya asuransi mobil. Sesuai dengan namanya yang merupakan kombinasi dari 2 kata yaitu 'auto' dan 'cillin' asuransi ini memberikan 'obat' untuk memulihkan 'luka' yang tidak hanya terbatas pada luka fisik pada kendaraannya. Namun lebih dari itu, Autocillin memulihkan luka batin pada pemilik kendaraan, menghapus kekecewaan dan ketidaknyaman setelah risiko terjadi.Melalui pendekatan tanda seperti yang telah dijabarkan di atas maka melalui identitasnya sebuah merek Autocillin siap untuk berinteraksi dan bersaing dengan merek-merek yang sudah lebih dahulu dikenal oleh masyarakat. 


\section{DAFTAR PUSTAKA}

Grefé, R. (2000). (Form+Content+Context) $/$ Time $=$ Experience Design. AIGA Journal for the Network Economy (Online), Volume 1, number 1 (http://www.aiga.org/resources/content/1/9/1/8/documents/experience design.pdf diakses 16 Juli 2009)

Schramm, W. (1954). The process and effects of communication. Urbana: University of Illinois Press.

Smith, D. (2010). Design for Content Management, diakses tanggal 15 Juli 2010 dari http://www.designartcraft.com/design/folio/design_content_mgt.pdf

Wheeler, A. (2003). Designing Brand Identity: A complete guide to creating, building and maintaining strong brands. New Jersey: John Wiley \& Sons. 